Brit. Heart f., 1967, 29, 60.

\title{
Aneurysm of the Membranous Ventricular Septum
}

\author{
ABNASH C. JAIN AND ROBERT ROSENTHAL \\ From the Department of Medicine, Sub-department of Cardiology, Albany Medical College, and Albany \\ Medical Center Hospital, Albany, New York, U.S.A.
}

\begin{abstract}
Aneurysm of the membranous portion of the interventricular septum is considered to be a rare congenital anomaly, and to date only a few publications have documented ante-mortem diagnoses. Taussig (1960) reviewed the published reports and was able to find 80 cases diagnosed at necropsy. Steinberg (1957), using angiocardiographic studies, reported the first living patient with this defect. Two recent reports brought the total number discovered by angiocardiography to 7 (Kasparian, Brest, and Novack, 1965; Edelstein and Charms, 1965). Using selective left ventricular angiocardiography we have found 10 patients at this centre during the past two years.
\end{abstract}

\section{Anatomy and Pathogenesis}

The membranous septum is the weakest portion of the interventricular septum. It not only separates the left ventricle from the right ventricle, but also the left ventricle from the right atrium behind the tricuspid valve (Larsen and Noer, 1960). Aneurysmal dilatation of this portion is usually of small size, varying from $1-3 \mathrm{~cm}$. in diameter. Rarely these sacs expand to obliterate the right atrium or the outflow tract of the right ventricle (Gould, 1960). When located in the muscular portion of the septum, these dilatations are usually considered to be acquired and many have been found in patients with a history of a myocardial infarction (Arons and O'Rourke, 1954; Valle-Cavero and Maquera, 1961). Most membranous aneurysms are congenital in origin, but cases due to trauma and infection have been described (Lev and Saphir, 1938). The most plausible theory for the development of an aneurysm in the membranous portion of the septum relates its formation to the natural spontaneous closure of a ventricular septal defect (Edelstein and Charms, 1965; Agustsson et al., 1963; Arcilla et al., 1963). Since this area is weak, the tissue responds to the pressure exerted by the left ventricle and bulges to the right.

Received February 2, 1966.

\section{Clinical Picture}

The clinical spectra of the 10 patients is summarized in the Table.

Age. The oldest patient was 20 and the youngest patient was 6 at the time of catheterization.

Sex. Male and female patients are equally distributed in this series.

Pre-catheterization Diagnosis. A ventricular septal defect was diagnosed in all but one patient, who was considered to have an atrial septal defect.

Signs and Symptoms. All the children were known to have had a heart murmur since birth or the murmur was discovered in early childhood. None of the patients was truly symptomatic. Cases 5 and 7 gave histories of repeated colds and easy fatiguability. Case 9 had undergone surgical repair for her ventricular septal defect one year before admission and was restudied because a murmur persisted and she had developed the electrocardiographic pattern of complete right bundle-branch block.

Physical examination of the heart revealed a Grade 2-4/6 pansystolic murmur in some and ejection type murmur in others. The murmur was heard in the left præcordium with maximal intensity in the third and fourth left intercostal spaces along the left sternal border. In some cases the murmur was accompanied by a thrill. The second sound in the pulmonary area was either accentuated or normal with normal splitting with respiration. The intensity, location, character, and radiation of the murmur in no way served to distinguish these patients from those with ventricular septal defects.

Electrocardiogram. All tracings were within normal limits except for Case 6 which had the electrocardiographic pattern of a complete right bundle-branch block.

Radiographic Appearance of the Heart and Lungs. 60 
TABLE

\begin{tabular}{|c|c|c|c|c|c|c|c|c|c|}
\hline $\begin{array}{l}\text { Case } \\
\text { No. }\end{array}$ & $\begin{array}{l}\text { Age } \\
\text { (yr.) }\end{array}$ & Sex & $\begin{array}{c}\text { Pre- } \\
\text { catheterization } \\
\text { diagnosis }\end{array}$ & Signs and symptoms & $\begin{array}{l}\text { Electro- } \\
\text { cardio- } \\
\text { gram }\end{array}$ & $\begin{array}{l}\text { Chest radio- } \\
\text { graph }\end{array}$ & $\begin{array}{l}\text { Cardiac catheter- } \\
\text { ization data }\end{array}$ & $\begin{array}{l}\text { Left ventricular } \\
\text { cine-angiograms }\end{array}$ & $\begin{array}{l}\text { Congenital } \\
\text { or acquired }\end{array}$ \\
\hline 1 & 20 & $\mathbf{F}$ & ASD & $\begin{array}{l}\text { Heart murmur at } 5 \text { mth.; } \\
\text { soft systolic grade } 2 \\
\text { murmur best heard at } \\
\text { pulmonary area; P2 } \\
\text { increased and split; } \\
\text { asymptomatic }\end{array}$ & Normal & $\begin{array}{l}\text { Prominent pul- } \\
\text { monary artery }\end{array}$ & $\begin{array}{l}\text { Gradient of } 10 \mathrm{~mm} \text {. } \\
\mathrm{Hg} \text { between } \mathrm{RV} \text { and } \\
\mathrm{PA} \text {; no oxygen step- } \\
\text { up on right side; } \\
\mathrm{PA} 20 / 5 ; \mathrm{RV} 30 / 0\end{array}$ & $\begin{array}{l}\text { Aneurysm of VS; } \\
\text { small VSD }\end{array}$ & Congenital \\
\hline 2 & 11 & $\mathbf{M}$ & VSD & $\begin{array}{l}\text { Asymptomatic; pansys- } \\
\text { tolic murmur and thrill } \\
\text { since birth; murmur } \\
\text { and thrill disappeared } \\
\text { in past five years; P2 } \\
\text { normally split }\end{array}$ & Normal & Normal & $\begin{array}{l}\text { Normal pressures and } \\
\text { no oxygen step-up }\end{array}$ & $\begin{array}{l}\text { Aneurysm of VS } \\
\text { and small septal } \\
\text { defect }\end{array}$ & Congenital \\
\hline 3 & 13 & $\mathbf{M}$ & VSD & $\begin{array}{l}\text { Murmur since infancy; } \\
\text { asymptomatic; systolic } \\
\text { thrill and grade } 3 \text { pan- } \\
\text { systolic murmur left } \\
\text { sternal border; P2 split }\end{array}$ & Normal & $\begin{array}{l}\text { Pulmonary vas- } \\
\text { culature slight- } \\
\text { ly increased }\end{array}$ & $\begin{array}{l}\text { Normal pressures and } \\
\text { no oxygen step-up } \\
\text { on right side of } \\
\text { heart }\end{array}$ & $\begin{array}{l}\text { Aneurysm of VS } \\
\text { and small septal } \\
\text { defect }\end{array}$ & Congenital \\
\hline 4 & 9 & $\mathbf{M}$ & VSD & $\begin{array}{l}\text { Murmur since infancy; } \\
\text { repeated upper res- } \\
\text { piratory catarrh; sys- } \\
\text { tolic thrill and grade } \\
3-4 \text { ejection systolic } \\
\text { murmur at left sternal } \\
\text { border (3rd and 4th } \\
\text { intercostal space) }\end{array}$ & Normal & $\begin{array}{l}\begin{array}{l}\text { Pulmonary } \\
\text { culature }\end{array} \\
\text { and } \\
\text { heart } \\
\text { slightly } \\
\text { size } \\
\text { creased }\end{array}$ & $\begin{array}{l}\text { Gradient of } 15 \mathrm{~mm} \text {. } \\
\text { Hg between RV and } \\
\text { PA; no oxygen step- } \\
\text { up on right side of } \\
\text { heart; PA } 20 / 5 \text {; } \\
\text { RV } 35 / 0\end{array}$ & $\begin{array}{l}\text { Aneurysm of VS; } \\
\text { small VSD }\end{array}$ & Congenital \\
\hline 5 & 9 & $\mathbf{F}$ & VSD & $\begin{array}{l}\text { Murmur since birth; re- } \\
\text { peated colds; grade 3-4 } \\
\text { ejection systolic mur- } \\
\text { mur over left præ- } \\
\text { cordium; P2 normally } \\
\text { split }\end{array}$ & Normal & $\begin{array}{l}\text { Pulmonary vas- } \\
\text { culature in- } \\
\text { creased }\end{array}$ & Normal & $\begin{array}{l}\text { Aneurysm of VS; } \\
\text { small VSD }\end{array}$ & Congenital \\
\hline 6 & 14 & $\mathbf{F}$ & $\begin{array}{l}\text { Questionable } \\
\text { VSD }\end{array}$ & $\begin{array}{l}\text { Heart murmur since } \\
\text { birth; asymptomatic; } \\
\text { grade 3-4 pansystolic } \\
\text { murmur over left præ- } \\
\text { cordium; P2 split }\end{array}$ & Normal & $\begin{array}{l}\text { Minimal full- } \\
\text { ness of pulmon- } \\
\text { ary artery }\end{array}$ & $\begin{array}{l}\text { Normal pressures; } \\
\text { step-up of oxygen; } \\
\text { PA } 85 \% \text {; aorta 97\%; } \\
\text { RA } 70 \%\end{array}$ & $\begin{array}{l}\text { Aneurysm of VS } \\
\text { with small VSD }\end{array}$ & Congenital \\
\hline 7 & 11 & $\mathbf{M}$ & VSD & $\begin{array}{l}\text { Heart murmur since } \\
\text { birth; some fatigua- } \\
\text { bility for one year; } \\
\text { grade } 3 \text { ejection sys- } \\
\text { tolic murmur left third } \\
\text { intercostal space; P2 } \\
\text { normal }\end{array}$ & Normal & Normal & Normal & $\begin{array}{l}\text { Small VSD and } \\
\text { ventricular sep- } \\
\text { tal aneurysm }\end{array}$ & Congenital \\
\hline 8 & 15 & $\mathbf{F}$ & VSD & $\begin{array}{l}\text { Heart murmur since } \\
\text { birth; grade } 3 \text { or } 4 \text { pan- } \\
\text { systolic murmur third } \\
\text { and fourth left inter- } \\
\text { costal space; P2 ac- } \\
\text { centuated; asympto- } \\
\text { matic }\end{array}$ & Normal & $\begin{array}{l}\text { Prominent pul- } \\
\text { monary artery }\end{array}$ & Normal & $\begin{array}{l}\text { Persistent left su- } \\
\text { perior vena cava; } \\
\text { small VSD and } \\
\text { ventricular sep- } \\
\text { tal aneurysm }\end{array}$ & Congenital \\
\hline 9 & 6 & $\mathbf{F}$ & $\begin{array}{l}\text { VSD (post- } \\
\text { op.) }\end{array}$ & $\begin{array}{l}\text { Murmur since birth; } \\
\text { cardiac failure at } 5 \text { years } \\
\text { of age; repair of VSD; } \\
\text { now thrill and grade } \\
3-4 \text { ejection systolic } \\
\text { murmur persisting in } \\
\text { third and fourth left } \\
\text { sternal border; asymp- } \\
\text { tomatic }\end{array}$ & Normal & $\begin{array}{l}\text { Slightly increased } \\
\text { lung markings }\end{array}$ & $\begin{array}{l}\text { Before repair RV and } \\
\text { PA pressures equal } \\
\text { to systemic pressure; } \\
\text { VSD but no aneur- } \\
\text { ysm before opera- } \\
\text { tion }\end{array}$ & $\begin{array}{l}\text { Small ventricular } \\
\text { aneurysm in } \\
\text { membranous } \\
\text { portion }\end{array}$ & Acquired \\
\hline 10 & 8 & $\mathbf{M}$ & $\begin{array}{l}\text { VSD; ques- } \\
\text { tion of pul- } \\
\text { monary } \\
\text { stenosis }\end{array}$ & $\begin{array}{l}\text { Heart murmur since age } \\
3 \text { years; thrill and sys- } \\
\text { tolic murmur in left } \\
\text { sternal border; P2 nor- } \\
\text { mal }\end{array}$ & Normal & $\begin{array}{l}\text { Increase in pul- } \\
\text { monary vascu- } \\
\text { lature }\end{array}$ & $\begin{array}{l}\text { Normal pressures; } \\
\text { step-up of oxygen } \\
\text { in pulmonary ar- } \\
\text { tery; oxygen satura- } \\
\text { tion: PA } 87 \% \text {; RA } \\
73 \% \text {; aorta } 98 \%\end{array}$ & $\begin{array}{l}\text { Aneurysm of } \\
\text { membranous } \\
\text { septum }\end{array}$ & Congenital \\
\hline
\end{tabular}

ASD atrial septal defect; VSD ventricular septal defect; PA pulmonary artery; RA right atrium; RV right ventricle.

normal limits in all parameters in three cases. The remainder had either prominent pulmonary artery segments or hypervascular lung fields or both. Heart size in one case was considered to show minimal enlargement in the transverse diameter.

Hamodynamic Studies. Five cases had absolutely normal pressures and oxygen saturation on both sides of the heart. Cases 6 and 10 showed oxygen step-ups in the pulmonary artery of 15 and 14 per cent, respectively, while the pressures were within normal limits. Cases 1 and 4 showed normal oxygen saturations but had gradients of $10 \mathrm{~mm}$. and $15 \mathrm{~mm}$. $\mathrm{Hg}$ across the pulmonary valve, respectively. Case 9 had pulmonary artery and right ventricular systolic pressures equal to systemic pressures before the surgical repair of the ventricular septum. 


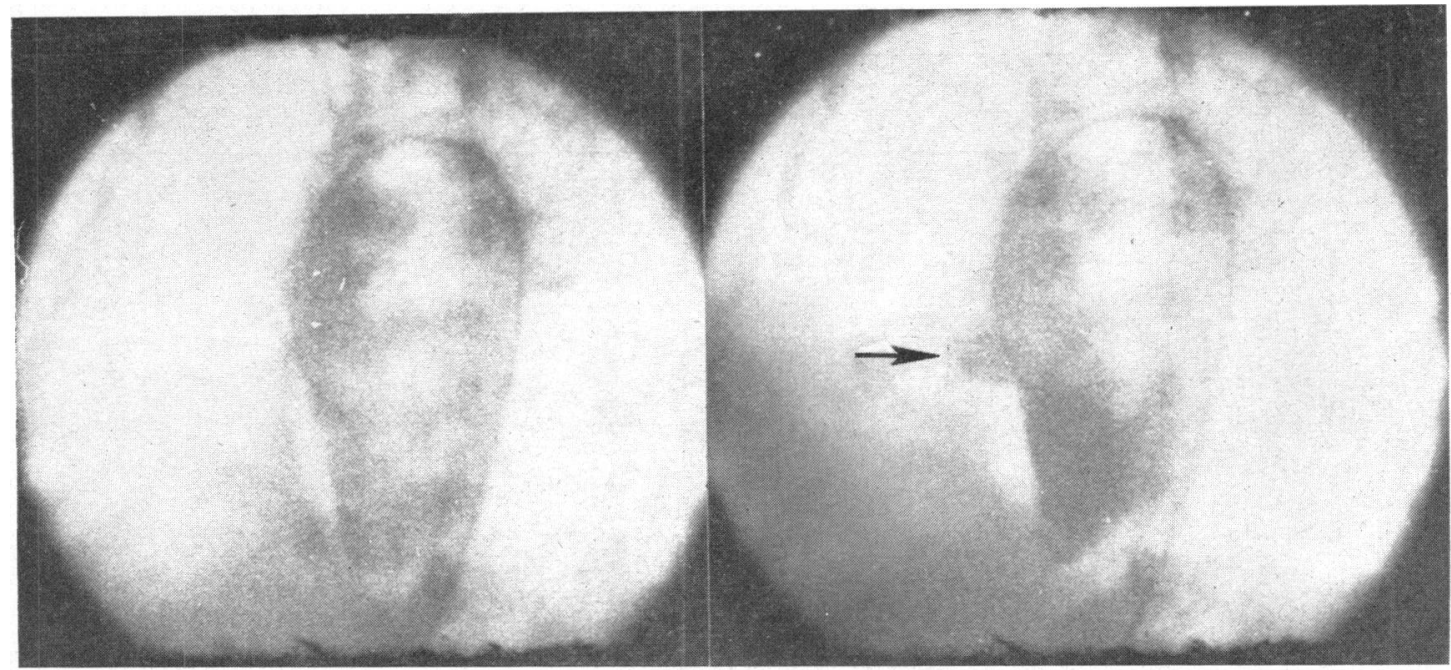

FIG.-Cine-angiogram of injection into the left ventricle. Oblique view of the heart. The frame to the left is taken during ventricular diastole and the frame to the right during systole. The arrow indicates the aneurysm.

One year after repair, repeat hæmodynamic studies were within normal limits.

Selective cine-angiographic studies of the left ventricle in postero-anterior and oblique views showed 1-3 cm. size aneurysmal dilatations of the membranous septum(Fig.).Most studies also demonstrated a small ventricular septal defect. Case 8 , in addition to a ventricular septal defect, showed a persistent left superior vena cava.

The following two narratives are of interest.

Case 2. An 11-year-old Caucasian boy was the fullterm product of unrelated parents. His mother had no ailments during the antenatal period. A loud grade $4 / 6$, pansystolic murmur and a thrill were detected in infancy and still noted at 5 years of age. Over the years the patient remained under strict medical surveillance. The thrill disappeared and the murmur was hardly audible at the time of catheterization at 11 years of age. The electrocardiogram, cardiac series, and other routine laboratory studies remained normal. Hæmodynamic studies showed normal pressures and oxygen saturations. Cine-angiocardiographic studies showed a $2 \times 1 \mathrm{~cm}$. aneurysm of the membranous portion of the interventricular septum and a small ventricular septal defect. No surgical intervention was contemplated and the patient remains under active medical follow-up.

Case 9. A 6-year-old Caucasian girl was the full-term product of unrelated parents. No ailments were encountered during the pregnancy. A harsh ejection systolic murmur of grade $3-4 / 6$ and a thrill were detected in the left præcordium in infancy. At 5 years of age, she developed mild congestive heart failure. Hæmodynamic studies at this time revealed a left-to-right shunt at the ventricular level. The right ventricular and pulmonary artery systolic pressures were equal to systemic pressure. The chest radiograph showed a slight increase in heart size, and the electrocardiogram was within normal limits. Cine-angiograms of the heart showed a ventricular septal defect in the upper portion of the septum. Surgical repair of this defect was carried out and the child had an uneventful post-operative course. A repeat cardiac catheterization was carried out due to the persistence of a thrill and a murmur. The data showed normal pressures and oxygen saturation. Cine-angiocardiograms revealed a $1.5 \times 1 \mathrm{~cm}$. aneurysm of the membranous septum and a residual ventricular septal defect. No further operations were carried out as the child became completely asymptomatic.

\section{FOLLOW-UP}

All 10 cases have remained asymptomatic. None of them warrant surgical intervention. As little is understood about the natural history of these aneurysms, a strict medical surveillance is considered necessary.

\section{Discussion}

Selective angiocardiography is the best means to diagnose membranous ventricular septal aneurysms, and they are consistently seen as an outpouching immediately below the root of the aorta (Edelstein and Charms, 1965).

The abnormalities most commonly associated with these aneurysms are aortic insufficiency (Leckert and Sternberg, 1950), membranous subaortic stenosis (Rae, 1936), complete atrioventricular block (Clark and White, 1952) and other arrhythmias (Rogers, Evans, and Domeier, 1952), mongolism (Lev and Saphir, 1938), and coarctation 
of the aorta (Kolesov, 1963). None of our cases showed the above associated features. Obstruction of the right ventricular outflow tract by an aneurysm was described by Das, Jahnke, and Walker (1964). Two of our cases showed mild pulmonary valve gradients. However, the gradient may represent mild valvular pulmonary stenosis rather than mild right ventricular outflow tract obstruction due to aneurysm. Rupture, infection, and thromboembolism have been documented (Peräsalo et al., 1961) as complications of septal aneurysms. All the cases in our series presented as ventricular septal defects; the clinical picture, and electrocardiographic and radiographic findings, did not help to differentiate them from classical uncomplicated ventricular septal defects.

It is intriguing to apply the hypothesis that these aneurysms of the membranous septum occur during the spontaneous closure of an interventricular septal defect. Especially in Case 2, we were convinced that the diminution in the intensity of the murmur, the disappearance of a thrill, and the normal radiograph and electrocardiographic findings together with the over-all well-being of this boy, represented closure of a septal defect. Since no studies were performed early in life, we do not know whether an aneurysm is a late manifestation or an early accompaniment of a ventricular septal defect. As yet, membranous septal aneurysms have not been documented in infancy.

With so little known as to the course of patients with this defect, we plan no immediate surgical intervention on patients who are asymptomatic. These patients are being followed closely and plans have been made to repeat the angiographic studies at appropriate intervals.

\section{SUMMARY}

Ten cases of membranous ventricular septum aneurysm (nine congenital and one acquired) have been described. Their clinical features, hæmodynamic and cine-angiographic studies have been outlined. The only sure way of diagnosing this anomaly is by selective angiocardiography.

\section{REFERENCES}

Agustsson, M. H., Arcilla, R. A., Bicoff, J. P., Moncada, R. and Gasul, B. M. (1963). Spontaneous functional closure of ventricular septal defects in 14 children demonstrated by serial cardiac catheterizations and angiocardiography. Pediatrics, 31, 958.

Arcilla, R. A., Agustsson, M. H., Bicoff, J. P., Lynfield, J., Weinberg, M., Jr., Fell, E. H., and Gasul, B. M. (1963). Further observations on the natural history of isolated ventricular septal defect in infancy and childhood. Serial cardiac catherization studies in 75 patients. Circulation, 28, 560.

Arons, J. J., and O'Rourke, P. (1954). Myocardial infarction with aneurysm of interventricular septum and perforation. F. Amer. med. Ass., 155, 1050.

Clark, R. J., and White, P. D. (1952). Congenital aneurysmal defect of the membranous portion of the ventricular septum associated with heart block, ventricular flutter, Adams-Stokes syndrome and death. Circulation, 5, 725.

Das, S. K., Jahnke, E. J., and Walker, W. J. (1964). Aneurysm of the membranous septum with interventricular septal defect producing right ventricular outflow obstruction. Circulation, 30, 429.

Edelstein, J., and Charms, B. L. (1965). Ventricular septal aneurysms. Circulation, 32, 981.

Gould, S. E. (1960). (ed.) Pathology of the Heart, 2nd ed. Charles C. Thomas, Springfield, Illinois.

Kasparian, H., Brest, A. M., and Novack, P. (1965). Congenital aneurysm of the membranous ventricular septum. Arch. intern. Med., 115, 753.

Kolesov, A. P. (1963). Aneurysms of the cardiac interventricular septum. Grud. Khir., 5, No. 5, p. 86.

Larsen, K. A., and Noer, T. (1960). Cardiac aneurysm of the membranous portion of the interventricular septum. Acta med. scand., 166, 401.

Leckert, J. T., and Sternberg, S. S. (1950). Congenital aneurysm of the membranous interventricular septum with unique anomaly of the pulmonary vessels. Amer. Heart F., 39, 768.

Lev, M., and Saphir, O. (1938). Congenital aneurysm of the membranous septum. Arch. Path., 25, 819.

Peräsalo, O., Halonen, P. I., Pyörälä, K., and Telivuo, L. (1961). Aneurysm of the membranous ventricular septum causing obstruction of the right ventricular outflow tract in a case of ventricular septal defect. Acta chir. scand., Suppl. 283, p. 123.

Rae, M. V. (1936). Congenital aneurysm of the interventricular septum complicated by subaortic stenosis and other anomalies. F. techn. Meth., 15, 136.

Rogers, H. M., Evans, I. C., and Domeier, L. H. (1952). Congenital aneurysm of the membranous portion of the ventricular septum: Report of two cases. Amer. Heart F., 43, 781.

Steinberg, I. (1957). Diagnosis of congenital aneurysm of the ventricular septum during life. Brit. Heart F., 19, 8.

Taussig, H. B. (1960). Congenital Malformations of the Heart, 2nd ed. The Commonwealth Fund, Harvard University Press, Cambridge.

Valle-Cavero, C., and Maquera, A. G. (1961). Acquired ventriculo-septal aneurysm with late spontaneous perforation of the septum. Amer. Heart f., 62, 698. 